Journal of Critical Race Inquiry

Vol. 5, No. 1 (2018) pp. 27-49

\title{
"We must use every legal means to ... put them behind bars, or to run them out of town"1: Assembling citizenship deservingness in Toronto
}

\section{Paloma Villegas \\ Department of Sociology, University of Toronto, Scarborough}

\begin{abstract}
This paper examines the assemblage and reassemblage of citizenship deservingness in Canada in the past few decades. By citizenship deservingness, I refer to the ways immigrant and racialized persons are accorded value and opportunity to access and retain formal citizenship status, including the right to remain in Canada. In order to make this argument, I examine the response to a 2012 shooting in Scarborough, an "inner suburb" of Toronto, Canada. I situate the shooting responses alongside policy and discursive changes that have made it easier to deport permanent residents from Canada if they have committed certain criminal acts. As scholars have noted, the targets of such policies are often the same individuals profiled and typecast as committing criminal acts - namely, immigrant and racialized men. In the Scarborough shooting, Jamaican men were specifically criminalized and targeted for exile from the city and country. My analysis demonstrates how, through this process, discourses of race and space came together to produce and legitimate policy changes that continue to erode the rights accorded to permanent residents and citizens.
\end{abstract}

Keywords: Citizenship, Deservingness, Assemblage, Race, Criminality

\footnotetext{
${ }^{1}$ Mayor Rob Ford, referring to the Danzig Street shooters (Kuitenbrouwer, 2012).
} 


\section{Introduction}

On July 16, 2012, a shooting at a Scarborough block party attended by several hundred people injured 23 and led to the deaths of Shyanne Charles and Joshua Yasay (Yang, Dempsey, Casey, \& Poisson, 2012). The shooting occurred on Danzig street, which houses Toronto Community Housing Corporation (TCHC) properties that provide subsidized housing for residents. Danzig street is located in Kingston Galloway Orton Park, in what has been called a "priority area" in Scarborough, one of Toronto's "inner suburbs" (Noble, 2009; Strong Neighborhoods Taskforce, 2005). The party was described as a "blocko"; a block party or "community barbecue ... based on a tradition of outdoor gatherings in the West Indies" (Vincent, 2012). As Vincent (2012) explained, "[d]ozens of these gatherings are held in Toronto Community Housing Corporation developments. They're intended as an opportunity to build bridges in these challenged communities and to get residents out of their units." The shooters were assumed to be of Black Jamaican origin and members of street gangs, which allowed media to portray this as part of the larger, so-called "gang crime" problem in Toronto. For instance, a Toronto Star article referred to the tragedy as "a deadly mass shooting and made 'Danzig' synonymous with violence” (Dempsey, 2012). Other stakeholders called for the deportation of the shooters, who were presumed to be immigrants because of their presumed racialized status (Alcoba, 2012a; Annable \& Learn, 2012; Cohen, 2012).

The Danzig shooting, and the responses to it, occurred in a context where, since the mid 1990s, there has been a push to more easily deport permanent residents in Canada deemed inadmissible due to "serious criminality." Currently, "serious criminality" is measured through a conviction punishable to a minimum of six months of prison time (Bechard \& Elgersma, 2012). This process is not unique to Canada; similar policies exist in Britain (Gibney, 2013) and the U.S. (Coutin, 2007).

In light of such policies, this paper draws on the Danzig events to illustrate the workings and shifts to a citizenship deservingness assemblage. Assemblage refers to the arrangement of different components that have fluid and contingent relationships to each other and produce particular effects of power. Citizenship deservingness refers to the production of "value" and how it is allocated to particular individuals depending on their relationship to understandings of "good" citizenship (Anderson, 2013; Willen, 2015). To demonstrate the assembled and reassembled nature of citizenship deservingness, I examine the intersection between racialized nation-building projects, constructions of place, and changes to immigration policy and practice. While the Danzig case is not representative of the rest of Canada, Scarborough's diversity and standing as an emerging immigrant gateway offers 
important insight into the ways in which race relations in major Canadian cities inform the nation's understanding of race and racialization, as well as the types of practices employed to navigate race and immigration. The Danzig case is also important given the social construction of Canada (and its institutions) as more inclusionary than the U.S., a facet of Canada's nationbuilding project that needs to be problematized.

\section{Conceptual Framing}

Four conceptual orientations inform my analysis. The first is the concept of assemblage. Assemblages are arrangements of components that come together to produce and inform social phenomena (Anderson, Kearnes, \& McFarlane, 2012; Daniel, 2013; DeLanda, 2006; Deleuze \& Guattari, 2005; Dittmer, 2014; Marcus \& Saka, 2006). They have been used to examine the composition of diverse events, phenomena, and social relations including global assemblages (Ong \& Collier, 2005), surveillant assemblages (Haggerty \& Ericson, 2000), and migration assemblages (Villegas 2013).

My conceptualization of assemblages focuses on five components: ways of knowing, or the knowledges produced about a particular topic; actors; institutions/organizations; technologies; and ways of feeling, or affect. These components are relational and contingent. They are relational in that they interact with other components and the nature of that interaction produces a particular outcome. Assemblages are contingent in that the outcome of the interaction with other components affects how they appear at a particular point in time, or their spatiotemporal context (Anderson et al., 2012; Dittmer, 2014; Jessop, Brenner, \& Jones, 2008). This means that an assemblage is not just the sum of its parts; rather its components extend and interact across assemblages and become reassembled as the spatiotemporal context shifts. For instance, immigration policy and understandings of "illegality" and criminality interact in specific ways depending on the spatiotemporal context. As new policies are enacted, so too are immigration discourses that reflect new forms of "knowledge" that are put to use by actors and institutions to exert power relations and circulate ways of feeling. This is often done through technologies - databases of information, border security apparatuses, forms of identification, etc.

The second conceptual orientation that informs my analysis is citizenship. Citizenship is usually described in two interrelated forms: formal and substantive citizenship. Formal, or thin, citizenship, as in birthright or naturalized citizenship, operates through legal documents and is often represented through a citizen/non-citizen dichotomy (Bosniak, 2006; Calavita, 2005). It refers to legal status only. Substantive or "thick" citizenship refers to the interplay 
between the rights afforded to citizens and the responsibilities they have to their communities and nation-state (Marshall, 1950). Substantive citizenship operates most explicitly in welfare states with thick safety nets and entitlements. However, it is not applied equally to all persons with formal status given interlocking forms of oppression. Therefore, citizenship is hierarchically organized and disproportionately denies some rights and responsibilities to marginalized groups including women, racialized peoples, working class communities, and immigrants regardless of their legal status (Bosniak, 2006).

While gradations of citizenship and membership exist, normative citizenship regimes often depict citizenship and non-citizenship as a binary. However, the boundaries between these categories can sometimes blur. That is, marginalized citizens can sometimes face similar forms of exclusion to social membership as non-citizens. Anderson (2013) has argued that individuals can be situated within, and move across, a spectrum of "good" citizens, "bad" citizens, and non-citizens.

This is where the third conceptual element emerges: constructions of deservingness. Deservingness refers to the subjective allocation of "value" or "worth" to individuals, spaces, and events; a process that involves a moral and therefore affective evaluation (Willen, 2012, 2015; Yarris \& Castañeda, 2015). Scholars have used the concept to examine how stakeholders open up or close off access to healthcare, welfare services, and social disaster relief using deservingness frames (Goldade \& Okuyemi, 2012; Reid, 2013; Skinner, Freeman, Feather, \& Roche, 2007; Willen, 2012; Yoo, 2002). Therefore, the concept is useful to understand not whether a deservingness frame is "true" or "fair," but rather to examine the ways different actors evaluate "worth" and mobilize strategies to support their position. For example, the deservingness of non-citizens is often evaluated through their tentative relationship to formal citizenship in a nation-state. Contemporary framings of citizenship deservingness draw on neoliberal understandings of productivity and "personal responsibility" vis-à-vis the acquisition of social goods (Mitchell, 2003). They also draw on assumptions that non-citizens engage in higher levels of criminal behaviour, which in turn leads to surveillance and policing strategies targeted at these populations (Aas \& Bosworth, 2010; Dowling \& Inda, 2013). And indeed, such surveillance and policing strategies are often informed by racial, class, and gender stereotypes (Yoo, 2002). Inda (2006) uses the term "anti-citizen" as a catchall term to capture how particular groups are identified and described as "bad" or "failed" citizens. He explains how the process of differentiation and normalization occurs: "Normal [emphasis added] people must protect themselves and be protected from the hordes of anticitizens - the criminal, the underclass, the homeless, the vagrants, the truly disadvantagedwho threaten their security and quality of life" (Inda, 2006, p. 126). Similarly, Weber (2013) 
points to how deservingness influences the allocation of good citizenship for those identified as bad or non-citizens: "...policing in contemporary societies comes to be directed at groups whose citizenship is in dispute, whether they are actual non-citizens or 'pseudo-citizens' such as former (and perpetually unforgiven) felons" (p. 6). What Weber (2013) and Inda (2006) point to is that the categories used to define "good" citizenship_ "bad," "failed," anti, pseudo, or non-citizens - exist along a spectrum to each other. Put differently, the categories used to define "good" citizenship are diverse in terms of legal status, presumed criminality, and behaviour. On the one hand we have non-citizens, lacking legal status, and on the other hand we have "bad" or "failed" citizens, who have legal status (formal citizenship) but have been found to lack an acceptable performance of the rights and entitlements associated with substantive citizenship.

Finally, the criminalization of bodies also extends to the criminalization and racialization of spaces, the fourth conceptual element. Therefore, theorizations of space can help interrogate the reassemblage of citizenship deservingness. Space, place, and social relations are co-constitutive and influence the circulation of power (Massey, 1994). Taking this into account, Kirby (1996) argues that "space and where we are in it ... determines a large portion of our status as subjects, and obversely, the kinds of subjects we are largely dictates our degree of mobility and our possible future locations" (p. 12). In this sense, space is productive; it produces particular subjectivities that, although contingent, shape how individuals understand themselves as well as how they are understood in society. McKittrick (2002) supports this argument, noting that "the spatialization of difference works to regulate the ways multiple identities occupy, or do not occupy space” (p. 28). Teelucksingh (2006) similarly argues that "racialized spaces are fundamental to how individuals, the state, and institutional practices make sense and manage ... race relations" (p. 9).

\section{Methods}

Data for this paper comes from media articles describing the Danzig shootings and their aftermath. I conducted a search of Canadian news sources (print and online) between 2014-2015, focusing on the period between the Danzig shooting (July 16, 2012) to April, 2015. The search netted a total of 93 sources.

I focus on news sources because they influence how the general public understands migration, particularly in relation to racialization and the identification of migrants as a "threat" to the national community (Bleich, Bloemraad, \& Graauw, 2015; Chavez, 2001; Estrada, Ebert, \& Lore, 2016; Mahtani, 2008; Santa Ana, 2002). I chose to focus on 
mainstream media because of its broad circulation and impact. Sources included the CBC, National Post, The Global and Mail, The Toronto Star, the Scarborough Mirror and Metro News. While the latter two sources are more local, the shooting occurred in Scarborough, which the Mirror covers, and the Metro is an accessible source available around the City of Toronto, leading to a wide readership. I also drew on immigration policy and grey literature, particularly City of Toronto and partner reports on specific Toronto neighbourhoods. Data was coded according to themes, focusing on the intersection between race, immigration status and space. My analysis for this paper draws on the themes of place and criminality; race and place; and race and immigration status. While these themes are interrelated, my analysis separates them for ease of discussion.

\section{Analysis}

\section{Place and Criminality}

The 2012 Danzig Street shooting occurred during a "block party" just steps outside the Kingston Galloway Orton Park (KGO) area of Scarborough. Scarborough is located in the east of the City of Toronto, and is regularly identified as an "inner suburb" (an "inner-city" area on the outskirts of the municipality with its associations to danger and criminality) (Basu, O’Connor, Fiedler, Ko, \& Prier, 2013; Harris, 2014). This designation is significant given the association of the "inner-city" with working class racialized and immigrant communities. In addition to its location in Scarborough, KGO has been identified as a "priority area" since 2005. "Priority areas" were conceived by the City of Toronto in 2004, after a report titled "Poverty by Postal Code: The Geography of Neighbourhood Poverty" was released in Toronto (United Way of Greater Toronto and the Canadian Council on Social Development, 2004). The report concluded that poverty had a spatial component and proposed focusing at the neighbourhood scale, given that "neighbourhood poverty has a devastating human cost and also damages the economic and social vitality of an entire region, affecting the quality of life for everyone in Toronto" (United Way of Greater Toronto and the Canadian Council on Social Development, 2004, p. iii).

Following the United Way report the City of Toronto, as part of the Strong Neighbourhoods Taskforce, released a report titled "Strong Neighbourhoods: A Call to Action" identifying specific areas in Toronto that were deemed "at risk," underserved, with "insufficient 'social infrastructure,' and a shortage of community space” (Leslie \& Hunt, 
2013; Strong Neighborhoods Taskforce, 2005). Funding and services focused on local level service provision that sought to strengthen local agencies, although with limited community consultation (City of Toronto, 2010). In 2014, the City changed the priority area designation to "Neighbourhood Improvement Areas" and KGO remained on the list as a result of its highdensity and public housing, and history of limited municipal investment in infrastructure (Contenta, Powell, \& Rankin, 2008; United Way of Greater Toronto and the Canadian Council on Social Development, 2004).

These municipal policies and actions demonstrate how political actors and the social services sector participate in the association of working class communities with criminality even when they "seek" to undo processes of marginalization. This process feeds into a citizenship deserving assemblage in that it involves the association of place with criminality, using, for example, "at-risk discourses" (Ahmed \& Carpenter, 2017). For instance, Ahmed and Carpenter (2017) link the priority neighbourhood project to discourses of civilization and the failures of a superficial approach to multiculturalism:

Priority Neighbourhoods express a contradiction within the liberal capitalist state wherein uncivil, degenerate spaces are constructed as racially and culturally separate from the body politic. However, such spaces have a complex, material role in the urban space as providers of low-wage labour and consumers of low-cost import commodities. The Priority Neighbourhood initiative attempts to address this contradiction by providing these neighbourhoods' the means to materially enter civil society through access to services, infrastructure, and the "rule of law". In reality, the Priority Neighbourhood initiative is one piece of a policy packet designed to incorporate racialized youth and other marginalized groups into civil society. (Ahmed \& Carpenter, 2017, p. 86)

Thus, Priority Neighborhoods act as an approach to "improve" spaces through a neoliberal logic of "good" citizenship and contribution. They also operate through a segregationist logic, spatially bounding communities through what Goldberg (1993) refers to as "periphractic space"; that is, a space that becomes bounded and influences social relations, locations, and subjectivities:

...the racial poor were simultaneously rendered peripheral in terms of urban location and marginalized in terms of power. This notion of periphractic space is relational: It does not require the absolute displacement of persons to or outside city limits, to the literal margins of urban space. It merely entails their circumscription in terms of location and their limitation in terms of access - to power, to (the realization of) rights, and to goods and services. The processes of spatial circumscription may be intentional 
or structural: They may be imposed by planners upon urban design at a specific time and place, or they may be insinuated into the forms of spatial production and inherent in the terms of social rationalization. Further, the circumscribing fences may be physical or imagined. In short, periphractic space implies dislocation, displacement, and division [emphasis added]. It has become the primary mode by which the space of racial marginality has been articulated and reproduced. (Goldberg, 1993, p. 188) KGO's designation as a "priority" and "neighborhood improvement area" leads to it being imagined, or "insinuated into the forms of spatial production," as abject. Goldberg's reference to "dislocation, displacement and division" is important here. The city, already divided into sections (previous municipalities including Scarborough and Etobicoke) and neighborhoods, had those spatial divisions evaluated in terms of social worth through city reports and policies. Dislocation also refers to the relegation and segregation of working class, racialized, and immigrant communities to such sites.

This context provides a backdrop through which to understand the Danzig shooting, the responses to and representations of which well-illustrate the relationship between space and criminality. For example, an article in the Globe and Mail on July 19, 2012 cited the event as Toronto's "largest mass shooting" (Appleby \& Morrow, 2012). Subsequent articles referred to the "Danzig shooting" linking a violent act to a specific site in Toronto: Danzig Street, KGO, Scarborough (Dempsey, 2012; Elliot, 2012, Morrow \& Appleby, 2012). This was despite much of that same coverage reinforcing the fact that crime rates had decreased in Toronto in relation to previous decades (Powell, 2012; Toronto Star, 2012a). Therefore, while crimes had decreased, the message sent was that pockets of "criminality" persisted in the city.

One particular focus was "gang turfs." An article in the Toronto Star on July 19, 2012 titled "Scarborough shootings: Old gang rivalries re-emerging, Police Chief Bill Blair suggests" alluded to the idea that the site around the shootings had a history of "turf" wars that were re-emerging (Donkin, 2012). The article referred to the "Galloway boys," a "street gang" that had "gripped parts of Scarborough in a violent turf war with a rival gang" (Donkin, 2012). The Galloway boys are named after Galloway Road, a street situated in KGO. Another article published in the National Post on July 19, 2012 reported that a person from the "Malvern Crew Gang" had been charged for the Danzig shooting (Annable, 2012). Malvern is another neighbourhood that has been identified as a "priority area" in the north of Scarborough.

These gangs were linked to these presumed "dangerous" neighbourhoods in the city, again marking "danger" as spatially bounded. An article in the National Post on December 22, 2012 cited Chief of Police Bill Blair "reflecting on the violence that plagues pockets of the 
city" and stating: "It's not a huge number of people, but there are young guys who just want to be the baddest guy, in the baddest neighbourhood, carrying the baddest gun belonging to the baddest gang. That's their ambition, that's what they want to do" (Alcoba, 2012a). The repetition of "baddest," from gun to guy, to gang to neighbourhood produced a scaling up, whereby the "baddest" neighbourhood was seen to be filled with the former person(s) and item(s). By referring to the individuals involved as "guy," Blair also drew on gender to reinforce the idea of a criminalized masculinity within the neighbourhood.

Similarly, an editorial published in Metro News on July 18, 2012 continued discussing the link between space and criminality, also addressing the neighbourhood scale. It stated:

Governments now need to act to address what feels like a troubling trend. It's not really about improving public safety - Toronto remains plenty safe — but rather about addressing neighbourhood-specific social issues [emphasis added] and sending a strong and coordinated message that, hey, we don't tolerate this kind of thing in our city. We're a better place than that. (Elliott, 2012)

By identifying the shooting as a "neighbourhood social issue," the editorial isolated the "problem" from the rest of the city, facilitating the identification of "criminal" spaces, inhabited by “criminal” subjects (D'Arcy, 2007; Henry, Hastings, \& Freer, 1996).

Through this association of space with criminality, the focus was placed not only on individuals - "good" versus "bad" citizens - but also on the public threat that "bad" citizens living in "bad" neighbourhoods (Malvern and Kingston Galloway/Orton Park, or KGO) with their associated "gangs" (Malvern Crew and Galloway Boys) have on "good" citizens (Annable \& Learn, 2012). Furthermore, identifying the shooting as a "neighbourhood specific issue" led the Scarborough "inner suburbs," including KGO, to continue to be seen as the "problem" (Elliott, 2012). They were again depicted as "pockets" that contain and, indeed, produce criminality, and while that criminality may permeate other areas, the latter can be cleansed of interlopers. Goldberg (1993) explains this spatial separation when he states "[c]itizens and strangers are controlled through the spatial confines of divided place. These geometries - the spatial categories through and in which the lived world is largely mapped, experienced, and disciplined — impose a set of interiorities and exteriorities" (p. 186). Interiorities and exteriorities operate themselves in at least two ways. First in terms of space, those who inhabit the "inner suburb" of Scarborough and its priority neighborhoods are depicted as outsiders to what becomes a superior downtown Toronto (in terms of perceived criminality and access to resources). This spatial construction overlaps with ideas of citizenship whereby those depicted as "bad" citizens become outsiders to appropriate social behavior. This boundary work results in what Yiftachel (2009) refers to as a "creeping urban 
apartheid," which is found through continued spatial segregation, lack of community consultation, and limited resources.

\section{Racialization of "Criminality" and Discourses of Citizenship}

In addition to the relationship between space and assumed criminality, the assumption of the shooters as Jamaican drew on readily available discourses of Black Jamaicans and criminality in the city (Burman, 2010). It is important to note that when the Danzig shooting first occurred, the identity of the shooters was unknown, and it was only their perceived connection with the Malvern Crew and Galloway Boys that led to their identification as Black Jamaican. $^{2}$

As Henry and Tator (2002) argue, public discourse and practice identifies racialized men as the "typical" perpetrators of violence, linking them to aggressive masculinity. Similarly, other scholars have identified the ways young Black men are represented in ways that criminalize them and their families as social threats (Collins, 2004; James, 2012; LadsonBillings, 2007). And given the historical effects of racism, exploitation, and carceral practices, Black males have faced an enforced hypermasculinity while at the same time being punished for it (Shabazz, 2015). These practices are also often organized through understandings of race as a cultural practice, often imported from "elsewhere" (Burman, 2010). As opposed to "biological racism," this type of racism identifies "cultural differences" as the category through which to categorize and hierarchize individuals (Balibar, 1993).

An article in the Globe and Mail published on October 22, 2012 referenced the Danzig shooting, stating:

The finger is often pointed - in some cases erroneously [emphasis added] —at street gangs that include Jamaican-Canadian members. The community has long grappled with gun crime in its midst, however, and the decades-old stereotype that JamaicanCanadians are involved in a disproportionate share of shootings. (Clark \& Morrow, 2012)

This example demonstrates how seemingly "well intentioned" journalists continue to draw on the links between racialization and criminality in problematic ways. While seeking to counteract dominant stereotypes about racialized criminality, the author's analysis did the opposite through the use of the phrase "in some cases," suggesting that pointing the finger at

\footnotetext{
${ }^{2}$ Several men and youth were eventually charged including for Nahom Tsegazab, Shaquan Mesquito and an unidentified 16 year old, however their connection to the two gangs discussed was never confirmed (Hasham, 2014; Poisson, 2012; Powe, 2014)
} 
Jamaican-Canadians was, in some cases, accurate.

The article also described a speech made by the Prime Minister of Canada Stephen Harper during a visit from the Prime Minister of Jamaica to Toronto. During the event, Harper was quoted as saying:

It has come to my attention that since July, many in this community, Toronto's Jamaican-Canadian community, feel that they live in the shadow of criminality arising out of incidents like the Danzig Street and Eaton Centre shootings ... Canadians understand that the only community placed under a shadow by perpetrators of these crimes is the community of criminals. People who came from Jamaica to Canada have come in search of a better life, and to contribute positively to our country, not to live in fear of street gangs and criminals. (Clark \& Morrow, 2012)

Harper's comments further pointed fingers by identifying two different types of "communities," or citizens: "good" Jamaican-Canadians "fighting" the stigma of criminalization and those who perpetrate violence - that is, "failed" or "bad" citizens. This division is an important demarcation of racial/immigrant respectability, vis-a-vis citizenship practices. In constructing the binary, Harper's comments performed a specific type of work. They identified Jamaicans as outside the national fold: they are Jamaican-Canadian and not Canadian-Canadian or, as discussed during the 2015 Federal election campaign "new stock" and not "old stock" Canadians (Oved \& Otis, 2015). We can see parallels between this instance and Abdel-Shehid's (2005) analysis of Olympic sprinter, Ben Johnson's, doping scandal. He states, "recall that in the aftermath of Johnson's positive drug test in Seoul, his identity moved from being 'Canadian' to 'Jamaican-Canadian' to 'Jamaican-born,'” a way for "state officials to name and identify [B]lackness at their whims" (p. 90).

Responses to the shooting from politicians also drew on the criminalization of families. In an article in the National Post published on July 19, 2012, Giorgio Mammoliti, a City Councillor, was cited asking

...councillors to reconsider one idea he floated a few years ago: a curfew of 10 p.m., or whenever the street lights are on, for anyone 14 or under.

"I think we're going to have a really bad summer with the gun [emphasis added]," he said. "To allow children to go out partying at night is the wrong thing to do. If the parents don't want to take control then the government should take control [emphasis added] and the only way we can do that is with a curfew." (Alcoba, 2012b)

Mammoliti's reference to "summer with the gun" pointed to the summer of 2005, labelled the "Summer of the Gun" (Doucette, 2012). The designation came from an observed increase in gun shootings across Toronto that year-20 shootings within a two-week period (Kern, 2010). 
As a response, Toronto police developed targeted activities including increased policing in what were deemed "areas experiencing an increase in violent activity" (Toronto Police, n.d.). This strategy increased community surveillance and reinforced the idea that certain areaspopulated by certain populations assumed to be more problematic-contain more criminal activity and require increased intervention (Annable, 2012).

Like Harper, Mammoliti's comments also point to a community, in this case a community of parents who were assumed to be so disengaged with their children's upbringing that disciplining them required government intervention. This is particularly problematic when directed at parents in a Black community, as it further perpetuates the perception of Black families as abnormal and Black parents as inadequate role models for their offspring (Collins, 2004). As hooks (2002) states, "[f]rom slavery to the present day the black family in the United States has been primarily represented in a negative light by unenlightened mainstream culture that is utterly biased in the direction of white supremacist capitalist patriarchy" (p. 120).

\section{Physical Expulsion: “Banishing” Immigrants and Reassembling Citizenship}

Canadian history is replete with instances of the physical and social exclusion of racialized peoples/immigrants. ${ }^{3}$ Such explicit race-based immigration exclusions did not end, on paper, until the 1960s with the liberalization of immigration policy (Li, 2003). The assemblage of components influencing citizenship access and deservingness became reassembled during that time, with an emphasis on skilled economic migration and the opening up of borders to racialized immigrants from the Global South (Simmons, 2010). It was also influenced by a discourse of multiculturalism that has rooted itself in the Canadian national imaginary since the 1970s. Despite this shift, as scholars have amply discussed, social exclusion on the basis of race and immigration have continued into the $21^{\text {st }}$ century (Bannerji, 2000; Thobani, 2007). Furthermore, the "gains" made in the mid-century have become eroded in recent years (Thobani, 2007).

One example of this erosion is the ability to deport permanent residents and citizens who are found guilty of serious criminality (measured through a conviction punishable to a minimum of six months of prison time), and thus deemed unworthy of the right to reside in Canada. Legal scholars and migrant justice activists ${ }^{4}$ have framed this process as a "double

\footnotetext{
${ }^{3}$ Some notable examples include Chinese exclusion (Simmons, 2010), the exclusion of Indian British subjects through the Continuous Journey regulation (Dua, 2007; Mongia, 2003), and Japanese internment (Oikawa, 2000).

${ }^{4}$ See for instance No One is Illegal, Toronto.
} 
punishment" because the criminal justice system was designed to "punish" criminal acts, yet immigration policy is now also used as an additional punishment directed, in particular, towards non-citizens (Hing, 2006).

There have been several policy reassemblings that have led to the current legal avenue to deport permanent residents in Canada. The possibility has been entrenched in policy since at least the mid-1990s. For instance, Bill C 44 in 1995 introduced deportation legislation into the Immigration Act. The bill was colloquially termed the Just Desserts Bill (Henry \& Tator, 2002, p. 196). It was influenced by the shooting of a white woman at Just Desserts, a café in an affluent Toronto neighbourhood, by a group of Jamaican Black men (Burman, 2010). Public outrage accompanied the case, leading to calls for changing immigration policy to disallow permanent residents with criminal records to remain in Canada, which resulted in the 1995 change. The Just Desserts Bill is therefore an example of how, despite falling crime rates in North America in the past few decades, the reaction to some crimes can create moral panics and the perception of insecurity, which in turn can influence, in particular, immigration policy (Farrell, Tilley, \& Tseloni, 2014).

In 2002, the Immigration Act was completely overhauled with the implementation of the Immigration and Refugee Protection Act (IRPA). Section 36(1) of the IRPA stated that a person could be liable for removal if they were "convicted in Canada of an offence under an Act of Parliament punishable by a maximum term of imprisonment of at least 10 years, or of an offence under an Act of Parliament for which a term of imprisonment of more than six months has been imposed" (Edelmann, 2013). However, if a person received a sentence of less than two years, they had the right to appeal the removal order. In 2013, the IRPA was amended with Bill C 43, the Faster Removal Of Foreign Criminals Act. As the title suggests, it allows for the faster removal of permanent residents convicted of criminality by reducing the pool of people who can appeal a deportation order to only those who have received a sentence of less than six months (Bechard \& Elgersma, 2012).

Finally, in 2015, Bill C 24 or the Strengthening Canadian Citizenship Act became fully implemented. The Act extended the realm of deportability to citizens, by making a series of policy changes to the acquisition and maintenance of citizenship status. One of its key aspects was an increased ability to revoke citizenship status for naturalized or dual citizens, particularly in relation to fraud and national security. These changes point to a trend: a decrease of the rights afforded by permanent residence and naturalized citizenship, particularly in relation to protection from deportation (Canadian Association of Refugee Lawyers, 2014). Justin Trudeau, elected Prime Minister in 2015, promised to make changes 
to the Citizenship Act. The changes occurred in 2017, pointing to another reassembling of citizenship policy.

In the case of the Danzig Street shootings, the perceived racialization of the shooters was further distorted when politicians referred to them as non-citizens, despite not knowing their legal status. Scholars have discussed the common conflation between racialized and immigrant subjects, a process of othering that bolsters white supremacy (Ahmed, 2000; Jiwani, 2006; Roberts \& Mahtani, 2010; Thobani, 2007). Burman (2010) argues that "Canadian state policy has a long history of criminalizing and racializing migrant groups, including Jamaicans and other Caribbeans" (p. 115). Therefore citizenship — in this case assumptions of who embodies "bad" or "failed" citizenship - is "visibly inscribed on bodies" and "appears embodied in skin color" (Romero, 2006, p. 49). This process works to deny full access to belonging despite the fact that some people and their families have resided in a place they have called home for generations. While not planned, the process demonstrates how policymakers utilise current events to legitimate policy agendas that reassemble citizenship deservingness.

In discussing the shooting, Mayor Rob Ford called for "criminals" to be exiled from Toronto (Toronto Star, 2012b; Keenan, 2014), and specifically called for federal immigration policy that would ban "gun criminals" from the city (Cohen, 2012; Dale \& Campion-Smith, 2012). In one of his comments, Ford called for the expulsion to occur locally to Brampton, a city that is part of the Greater Toronto Area that has faced its own racializing and negative representations, particularly in relation to South Asians (Keenan, 2014).

In an article on July 19, 2012 from the National Post, Ford went on to say: "I want these people out of the city ... Not put them in jail and then come back and you can live in the city. No, I want them out of the city" (Alcoba, 2012b). Ford's comments depict what D'Arcy (2007) has referred to as "imported crime," the mobilization of discourse that identifies criminal activity in Toronto coming from elsewhere-oftentimes the Caribbean. In doing so, Ford participated in a process that allowed for the rationalization of removing residency or citizenship status from those stereotyped as foreigners or non-citizens, despite their formal legal status. Therefore, his comments, as outlandish as they may have sounded, pointed to the fact that there is space in the Canadian social imaginary for the banishment of citizens: from the city as well as the country. By alluding to immigration policy and using terms such as "banishing," Ford drew on discourses of migrant "illegality," shifting the boundaries of "bad" or "failed" citizenship into those of non-citizenship (De Genova, 2004).

Ford's call for deporting the shooters gained further traction when then-Minister of Immigration Jason Kenney responded. Initially, Kenney tweeted: "I agree w/ Mayor Ford: 
foreign gangsters should be deported w/out delay" (Bryden, 2012a). After receiving criticism, Kenney's spokespeople "clarified" that in his comments, he was agreeing "with the principle that foreign criminals generally should be removed from Canada more quickly" (Bryden, 2012b). Kenney went on to state that

...clearly, the recent rash of gun crime in Toronto is connected to criminal gang activity and we are aware that there have been foreign members, sometimes leading members of criminal gangs in Canada, able to recommit offences while delaying their deportation. (Bryden, 2012b)

While retracting his most explicit comment, Kenney nonetheless connected "criminal gang activity" with immigration, identifying perpetrators of the former as not only "foreigners," but also deportable immigrants. The 2013 Faster Removal of Foreign Criminals Act was introduced to Parliament in June of 2012, only a month before the Danzig shooting, and Kenney used the Danzig case as a rationale for why such policy was needed. In doing so, his actions brought together discourses of criminality, city "safety," and immigration policy and removal. It further contributed to the reassembling of citizenship, bolstering an already existing process of deporting permanent residents from Canada.

\section{Discussion and Conclusion}

As the reactions to the Danzig shooting demonstrate, the boundaries of citizenship can become reassembled due to what may appear a series of unrelated events. The Danzig shooting involved the production of particular narratives around race, space, and immigration status through a set of actors - namely, policy makers and journalists - as well as institutions such as the media, different layers of government, the police, and social service organizations. These events also engendered particular reactions, including a sense of threat and a need to cleanse "valued" city spaces of those deemed "outsiders," whether from the city's "inner suburbs" and/or from outside of Canada. Those assumed to be the perpetrators of the shooting were, as a result of their relationship to place and presumed criminality, depicted as undeserving of any legal residency status.

Responses to the Danzig shooting are therefore one component of a citizenship deservingness assemblage. They became assembled with other components. First, there were changes to citizenship policy for racialized immigrants from the Global South in the 1960s and 1970s because of a liberalization of immigration policy, as well as Canada's "commitment" to "Multiculturalism." Such changes created the façade that racialized groups had equal access to citizenship and, by extension, citizenship deservingness. Second, 
criminalization of Scarborough and "priority areas" led to a spatial separation of the resourcerich downtown core and the city's "inner suburbs." Third, the racialization of perceived criminality in Toronto - influenced by the Just Desserts shooting in the 1990s, the 2005 "Summer of the Gun," and the subsequent changes to immigration policy - facilitated the deportation of permanent residents in the 1990s, 2000s and 2010s, each iteration allowing for increased deportability of permanent residents and citizens.

The fixing of individual bodies and particular identities to Toronto's "priority areas," which are in turn imagined to produce violence and "bad" or "failing" citizens, allowed for the subsequent removal of those bodies outside of the city and the nation. Therefore, instead of a focus on the victims of the Danzig shooting and the need to revitalise marginalized spaces, policymakers and media alike responded to the shooting in ways that prioritised linking the shooters to their assumed race and immigrant status, and the shooter's associated neighbourhoods with criminality and race.

\section{References}

Aas, K. F., \& Bosworth, M. (2010). The borders of punishment: Migration, citizenship, and social exclusion ( $1^{\text {st }}$ ed.). Oxford, UK: Oxford University Press.

Abdel-Shehid, G. (2005). Who da man?: Black masculinities and sporting cultures. Toronto, ON: Canadian Scholars' Press.

Ahmed, A., \& Carpenter, S. (2017). The Ontario Youth Outreach Worker Program as racialized spatial praxis. In S. Carpenter \& S. Mojab (Eds.), Youth as/in crisis: Young people, public policy, and the politics of learning (pp. 81-93). Rotterdam, NL: Sense Publishers.

Ahmed, S. (2000). Strange encounters: Embodied others in post-coloniality. New York: Routledge.

Alcoba, N. (2012a, December 22). Breaking down budgets and gun crime: Blair on gangs. National Post, p. A15.

Alcoba, N. (2012b, July 19). Ford to ask premier for dedicated police officers: Anti-violence strategy. National Post, p. A7.

Anderson, B., Kearnes, M., \& McFarlane, C. (2012). On assemblages and geography. Dialogues in Human Geography, 2(2), 171-189.

Anderson, B. (2013). Us and them? The dangerous politics of immigration control. Oxford, UK: Oxford University Press. 
Annable, K. (2012, July 25). Examining the Toronto Police TAVIS program. National Post. Retrieved from http://www.nationalpost.com.

Annable, K., \& Learn, J. R. (2012, July 19). From "little stabbings" to mass shootout: Residents fear for the worst as violence in neighbourhood reaches new height. National Post. Retrieved from http://www.nationalpost.com.

Appleby, T., \& Morrow, A. (2012, July 19). Mayor calls on Harper, province to help fight gangs. Globe \& Mail, p. A1.

Balibar, E. (1993). Is there a Neo-Racism? In E. Balibar \& I. M. Wallerstein (Eds.), Race, Nation, Class: Ambiguous Identities (pp. 17-28). London, UK: Verso.

Bannerji, H. (2000). The dark side of the nation: Essays on multiculturalism, nationalism and gender. Toronto, ON: Canadian Scholars' Press.

Basu, R., O’Connor, K., Fiedler, R., Ko, C., \& Prier, N. (2013). Integrative multiplicity through suburban realities: Exploring diversity through public spaces in Scarborough (pp. 1-62). Toronto, ON: The Centre of Excellence for Research on Immigration and Settlement (CERIS).

Bechard, J., \& Elgersma, S. (2012). Bill C-43: An Act to Amend the Immigration and Refugee Protection Act (Faster Removal of Foreign Criminals Act) (pp. 1-16). Ottawa, ON: Social Affairs Division: Parliamentary Information and Research Service.

Bleich, E., Bloemraad, I., \& Graauw, E. (2015). Migrants, minorities and the media: Information, representations and participation in the public sphere. Journal of Ethnic and Migration Studies, 41(6), 857-873.

Bosniak, L. (2006). The citizen and the alien: Dilemmas of contemporary membership. Princeton, NJ: Princeton University Press.

Bryden, J. (2012a, September 19). Jason Kenney tweet on 'foreign gangsters' and Toronto shooting lands minister in hot water. Huffington Post Canada. Retrieved from http://www.huffingtonpost.ca.

Bryden, J. (2012b, July 21). Outrage over Kenney's tweet after shooting 'foreign gangsters' comment riles MPs, Caribbean-Canadians. Winnipeg Free Press, p. A19.

Burman, J. (2010). Transnational yearnings: Tourism, migration, and the diasporic city. Vancouver, BC: UBC Press.

Calavita, K. (2005). Law, citizenship, and the construction of (some) immigrant "Others." Law \& Social Inquiry, 30 (2), 401-420.

Canadian Association of Refugee Lawyers. (2014, May 6). Press release: New citizenship act threatens rights of all Canadians. Retrieved from http://www.carl-acaadr.ca. 
Chavez, L. R. (2001). Covering immigration : Popular images and the politics of the nation. Berkeley, CA: UC Press.

City of Toronto. (2010). Backgrounder: 2006 Census update on social risk factors in the city's 13 priority areas. Retrieved from http://www.toronto.ca.

Clark, C., \& Morrow, A. (2012, October 23). As Jamaican PM visits, Harper speaks of crime and community, Globe and Mail, p. A4.

Cohen, T. (2012, July 24). Gun violence prompts mayor, PM to meet: Ford wants criminals who use firearms barred from Toronto, Edmonton Journal, p. A13.

Collins, P. H. (2004). Black sexual politics: African Americans, gender, and the new racism. New York: Routledge.

Contenta, S., Powell, B., \& Rankin, J. (2008, July 19). Poor services leave kids easy prey to gangs, Toronto Star, p. ID1.

Coutin, S. B. (2007). Nations of emigrants: Shifting boundaries of citizenship in El Salvador and the United States. Ithaca, NY: Cornell University Press.

D'Arcy, S. (2007). The "Jamaican criminal" in Toronto, 1994: A critical ontology. Canadian Journal of Communication, 32(2), 241-259.

Dale, D., \& Campion-Smith, B. (2012 July 20). McGuinty, mayor spar over solutions: Ford says he'll talk to PM about using 'immigration laws' to battle gun crime. Toronto Star, p. A1.

Daniel, D. (2013). The melancholy assemblage: Affect and epistemology in the English Renaissance (1st ed.). New York, NY: Fordham University Press.

De Genova, N. (2004). The legal production of Mexican/migrant "illegality." Latino Studies, $2(2), 160-185$.

DeLanda, M. (2006). A new philosophy of society: Assemblage theory and social complexity. London, UK: Continuum.

Deleuze, G., \& Guattari, F. (2005). A thousand plateaus: Capitalism and schizophrenia. Minneapolis, MN: University of Minnesota Press.

Dempsey, A. (2012, September 13). Danzig St. shooting taints quiet neighbourhood. Toronto Star. Retrieved from http://www.thestar.com.

Dittmer, J. (2014). Geopolitical assemblages and complexity. Progress in Human Geography, $38(3), 385-401$.

Donkin, K. (2012, July 19). Scarborough shootings: Old gang rivalries re-emerging, Police Chief Bill Blair suggests. Toronto Star. Retrieved from http://www.thestar.com.

Doucette, C. (2012, July 29). Toronto's sad history of gun-related violence. Toronto Sun. Retrieved from http://www.torontosun.com. 
Dowling, J. A., \& Inda, J. X. (2013). Governing immigration through crime: A reader. Stanford, CA: Stanford University Press.

Dua, E. (2007). Exclusion through inclusion: Female Asian migration in the making of Canada as a white settler nation. Gender Place and Culture, 14(4), 445-466.

Edelmann, P. (2013). Immigration consequences at sentencing. Paper prepared for Legal Services Society. Retrieved from Legal Services Society website: http://www.lss.bc.ca.

Elliott, M. (2012, July 18). Danzig shootings: After the mourning, what's next for Rob Ford and council? Metro News. Retrieved from http://www.metronews.ca.

Estrada, E. P., Ebert, K., \& Lore, M. H. (2016). Apathy and antipathy: Media coverage of restrictive immigration legislation and the maintenance of symbolic boundaries. Sociological Forum, 31(3) 555-76.

Farrell, G., Tilley, N., \& Tseloni, A. (2014). Why the crime drop? Crime and Justice, 43(1), 421-490.

Gibney, M. J. (2013). Deportation, crime, and the changing character of membership in the United Kingdom. In K. F. Aas \& M. Bosworth (Eds.), The borders of punishment: Migration, citizenship, and social Exclusion (pp. 218-236). Oxford, UK: Oxford University Press.

Goldade, K., \& Okuyemi, K. (2012). Deservingness to state health services for South-South migrants: A preliminary study of Costa Rican providers' views. Social Science \& Medicine, 74(6), 882-886.

Goldberg, D. T. (1993). Racist culture: Philosophy and the politics of meaning. Cambridge, MA: Blackwell.

Haggerty, K. D., \& Ericson, R. V. (2000). The surveillant assemblage. The British Journal of Sociology, 51(4), 605-622.

Harris, R. (2014). Using Toronto to explore three suburban stereotypes, and vice versa. Environment and Planning A, 47(1), 30-49.

Hasham, A. (2014, April 12). Danzig shootings guilty plea cold comfort for grief-stricken. Toronto Star, p. A1.

Henry, F., Hastings, P., \& Freer, B. (1996). Perceptions of race and crime in Ontario: Empirical evidence from Toronto and the Durham region. Canadian Journal of Criminology, 38(4), 469-476.

Henry, F., \& Tator, C. (2002). Discourses of domination: Racial bias in the Canadian Englishlanguage press. Toronto, ON: University of Toronto Press.

Hing, B. O. (2006). Deporting our souls: Values, morality, and immigration policy. Cambridge, MA; New York, NY: Cambridge University Press. 
Inda, J. X. (2006). Targeting immigrants: Government, technology, and ethics. Malden, MA; Oxford, UK: Blackwell Publishing.

James, C. E. (2012). Students "at risk": Stereotypes and the schooling of Black boys. Urban Education, 47(2), 464-494.

Jessop, B., Brenner, N., \& Jones, M. (2008). Theorizing sociospatial relations. Environment and Planning D: Society and Space, 26(3), 389-401.

Jiwani, Y. (2006). Discourses of denial: Mediations of race, gender, and violence. Vancouver, BC: UBC Press.

Keenan, E. (2014, July 19). Danzig neighbours show genuine leadership. Toronto Star, p. A4.

Kern, L. S. (2010). Selling the 'scary city': Gendering freedom, fear and condominium development in the neoliberal city. Social \& Cultural Geography, 11(3), 209-230.

Kirby, K. M. (1996). Indifferent boundaries: Spatial concepts of human subjectivity. New York, NY: The Guilford Press.

Kuitenbrouwer, P. (2012, July 17). Block party takes deadly turn: The two solitutdes of Toronto. National Post. Retrieved from http://www.nationalpost.com.

Ladson-Billings, G. (2007). Pushing past the achievement gap: An essay on the language of deficit. The Journal of Negro Education, 76(3), 316-323.

Leslie, D., \& Hunt, M. (2013). Securing the neoliberal city: Discourses of creativity and priority neighborhoods in Toronto, Canada. Urban Geography, 34(8), 1171-1192.

Li, P.S. (2003). Destination Canada: Immigration debates and issues. Don Mills, ON: Oxford University Press.

Mahtani, M. (2008). How are immigrants seen and what do they want to see? Contemporary research on the representation of immigrants in the Canadian English-language media. In J. Frideres, M. L. Burstein \& J. Biles (Eds.), Immigration and integration in Canada in the twenty-first century (pp. 231-252). Kingston, ON: McGill-Queen's University Press.

Marcus, G. E., \& Saka, E. (2006). Assemblage. Theory, Culture \& Society, 23(2-3), 101-106.

Marshall, T. H. (1950). Citizenship and social class, and other essays. Cambridge, UK: University Press.

Massey, D. (1994). Space, place and gender. Minneapolis, MN: University of Minnesota Press.

McKittrick, K. (2002). "Their blood is there, and they can't throw it out": Honouring Black Canadian geographies. Topia, 7, 27-37.

Mitchell, K. (2003). Educating the national citizen in neoliberal times: From the multicultural self to the strategic cosmopolitan. Transactions of the Institute of British 
Geographers, 28(4), 387-403.

Mongia, R. V. (2003). Race, nationality, mobility: A history of the passport. In A. Burton (Ed.), After the imperial turn: Thinking with and through the nation (pp. 196-214). Durham, NC: Duke University Press.

Morrow, A., \& Appleby, T. (2012, November 9). 18-year-old faces 27 charges for Danzig shootings - two for first-degree murder. Globe and Mail, p. A1.

Noble, M. (2009). Lovely spaces in unknown places: Creative city building in Toronto's inner suburbs (Research paper). Toronto, ON: Cities Centre, University of Toronto.

Oikawa, M. (2000). Cartographies of violence: Women, memory, and the subjects of the internment. Canadian Journal of Law and Society, 15(2), 39-68.

Ong, A., \& Collier, S. J. (2005). Global assemblages, anthropological problems. In A. Ong \& S. J. Collier (Eds.), Global assemblages: Technology, politics, and ethics as anthropological problems (pp. 3-21). Malden, MA: Blackwell Publishing.

Oved, M. C., \& Otis, D. (2015, September 18). Who are 'old stock Canadians'? Toronto Star. Retrieved from http://www.thestar.com.

Poisson, J. (2012, December 4). Danzig St. shooting: More charges for 16-year old in aftermath. Toronto Star. Retrieved from http://www.thestar.com.

Powe, P. (2014, April 11). Man gets 14 years after pleading guilty to manslaughter in Danzig shooting. The Globe and Mail. Retrieved from www.theglobeandmail.com.

Powell, B. (2012, November 26). How many officers do we need? The debate rages on over the size of the Toronto force with crime rates falling and police budgets soaring. Toronto Star, p. GT1.

Reid, M. (2013). Social policy, 'deservingness' and sociotemporal marginalization: Katrina survivors and FEMA. Sociological Forum, 28(4), 742-763.

Roberts, D. J., \& Mahtani, M. (2010). Neoliberalizing race, racing neoliberalism: Placing "race" in neoliberal discourses. Antipode, 42(2), 248-257.

Romero, M. (2006). Racial profiling and immigration law enforcement: Rounding up of usual suspects in the Latino community. Critical Sociology, 32(2-3), 447-473.

Santa Ana, O. (2002). Brown tide rising: Metaphors of Latinos in contemporary American public discourse. Austin, TX: University of Texas Press.

Shabazz, R. (2015). Spatializing blackness: Architectures of confinement and black masculinity in Chicago. Chicago, IL: University of Illinois Press.

Simmons. (2010). Immigration and Canada: Global and transnational perspectives. Toronto, ON: Canadian Scholar's Press. 
Skinner, N., Freeman, T., Feather, N. T., \& Roche, A. (2007). Stigma and discrimination in health-care provision to drug users: The role of values, affect, and deservingness judgments. Journal of Applied Social Psychology, 37(1), 163-186.

Strong Neighborhoods Taskforce. (2005). Strong neighborhoods: A call to action...A report of the Strong Neighourhoods Task Force (pp. 1-42). Strong Neighborhoods Taskforce, Toronto, ON.

Teelucksingh, C. (2006). Claiming space: Racialization in Canadian cities. Waterloo, ON: Wilfrid Laurier University Press.

Thobani, S. (2007). Exalted subjects: Studies in the making of race and nation in Canada. Toronto, ON: University of Toronto Press.

Toronto Police. (nd). What is TAVIS? Retrieved from Toronto Police website: http://www.torontopolice.on.ca.

Toronto Star. (2012a, October 2). 'Not too bad' not good enough. Toronto Star, p. A14.

Toronto Star. (2012b, December 29). Ford abides, but why? Toronto Star, p. IN6.

United Way of Greater Toronto and the Canadian Council on Social Development. (2004). Poverty by postal code: The geography of neighbourhood poverty, 1981-2001, Executive Summary (pp. 1-11). Toronto United Way of Greater Toronto and the Canadian Council on Social Development.

Villegas, P. E. (2013). Assembling a visa requirement against the Mexican 'wave': Migrant illegalization, policy and affective 'crises' in Canada. Ethnic and Racial Studies, $36(12), 2200-2219$.

Vincent, D. (2012, July 20). 'Blocko' parties have a long history in Toronto. Toronto Star. Retrieved from http://www.thestar.com.

Weber, L. (2013). Policing non-citizens. London, UK: Routledge.

Willen, S. S. (2012). Migration, "illegality," and health: Mapping embodied vulnerability and debating health-related deservingness. Social Science \& Medicine, 74(6), 805-811.

Willen, S. S. (2015). Lighting rods in the local moral economy: Debating unauthorized migrants' deservingness in Israel. International Migration, 53(3), 70-86.

Yang, J., Dempsey, A., Casey, L., \& Poisson, J. (2012, July 21). Scarborough shootings: What really happened on Danzig? Toronto Star. Retrieved from http://www.thestar.com.

Yarris, K., \& Castañeda, H. (2015). Discourses of displacement and deservingness: Interrogating distinctions between "economic" and "forced" migration. International Migration, 53(3), 64-69. 
Yiftachel, O. (2009). Theoretical notes on 'gray cities': The coming of urban apartheid? Planning Theory, 8(1), 88-100.

Yoo, G. J. (2002). Constructing deservingness: Federal welfare reform, supplemental security income, and elderly immigrants. Journal of Aging and Social Policy, 13(4), 17-34. 